\title{
Writing (Lines) Alive
}

\author{
Linda Marie Walker
}

\section{First half, four scenarios}

\section{Scenario one}

Where to be - personally, as a person, as a living-creature, or how to-be, how to hold oneself physically, mentally, emotionally, when writing a text, this one, now - is the thought this writing begins with, that initiates, or initialises, this collection of words, and temperamentally affects further thoughts as they come to mind. This makes writing, in its making (and in public form), propositional; propositional in its sense, its language, its relation, or reticence perhaps, toward (its blows upon) the body (like weather, voices, health, sleep) - and in its incapacity, or tenderness, to do what writing's supposed to do, or meant to achieve. Two "difficulties" arise, whose images, as ideas, may crinkle-up what comes after their vague descriptions. "Difficulty" though is already contestable, as in "difficulty" lies a type of work; this is work that paves the way for ease, or so as to come to ease, to "doing" and "making" inside "difficulty" itself. Nevermind, and, in fact, this "technic" of the-difficult may only suggest a "plying”, a way of working, handling, weaving, constructing, joining, a "going-on" into the medium (or material - of fibers, cell, words, memories, forests, etc), of cracks, fissures, knots, holes, splits. ${ }^{1}$ Difficulty splits: $d i=$ apart (or not) and facilis = doable, makeable, yieldable (and then "facilitate", to make easier); and so difficult (caulked) gives: apart from (or not) easily doable.

The first "di-facilis" is: I take care of who or what I am in the scenario of the writing; the second "di-facilis" is: I easily (facilitate) slip and fall and cause a scenario that will have to be taken care of too, or will in some unknown way help or hinder me and the writing (I can fall apart, seize up, require repair (maybe even caulk up the crack)). Where does one put oneself, or leave oneself, to write a text about "something" even though, simultaneously "something" has to-do with one's self (being one's time, and thought, and labour); nevertheless, it is the "topic of something" that the writing is usually used for, the "topic" is the "about" of the writing, or so it seems, and one's self is not the "about" of the writing (or not announced as such). Writing takes fits and starts, bits and pieces, adding and subtracting, scratching and scribbling, glue, sticky tape; time is the heart of the process, the passing of life, the life-span. The time of life comes into writing, and writing comes into the life of time, into the taking-to-heart (or, taking-into-heart) of living: at what point in life is the person-state, and what "governs" this point amongst other infinite governed points in the world; this is an issue at play in the writing of writing (in imagining that writing has its own imaginative life), or the conduct of life as a life writes-writing. ${ }^{2}$

1 Leonard Cohen's lyrics for "Anthem", from the 1992 album The Future, includes: "There is a crack in everything/That's how the light gets in."; Hélène Cixous writes, “The ark has a crack, where the worms that chew our lives during our lifetime come in. I caulk it" (2011:76).

2 lam touching upon the work here of James Hillman (2007)

\section{Scenario two}

In Michel Foucault's lecture from February 17, 1982, one in a series of 24 lectures given as a course titled "The Hermeneutics of the Subject", he talks about the careof-self in relation to knowledge-of-self, and this knowledge necessitating what he calls a return to (one)self. This return is an ancient return, and care is not "care" as commonly understood; rather, it is a type of preparation for this world, for the self who is in "this world", and for the self who must be free to leave "this world": 
It is not just a matter of attending to yourself, of focusing your gaze on your self, or remaining alert and vigilant with respect to yourself, as in the ... "naked" idea of the care of the self. It involves a real shift, a certain movement of the subject with regard to himself, whose nature we will have to investigate. The subject must advance towards something that is himself. (2001: 248)

I was already wondering who was writing this text at the time of coming again to Foucault's lecture. The wondering, initially, was not so much "who", but "how": how is it that writing, a writing, comes to be what it is; where does it begin, for how long has it been coming, and in the wake of what pleasures and displeasures and their conscious and unconscious affects; that is, what is a writing's passage, what is its life before life, as it comes to life, into the rhythms of phenomena, of things and conditions; what is it in the minuteness of its substance, in the face of the vastness of existing writing, and what am I in its eyes.

One absorbs the loss of oneself in the writing-topic; one ignores or side-lines one's self (out of sight and sound, feigns one's disappearance) for the produced-thing. Soon one forgets that one has vanished for the "interests" over one's own live body (one has died right before one's work). And yet, only I can be the one writing, the one enmeshing in the process of conjuring words, of trying to remember me, as I pass before my own eyes on the page. This remembering is, in the relationship (or return) to self (me), an act (however small) to recall-to-memory what has happened, what is happening now - with the animals, the weather, the law, the food, the family, the garden; what is to-be remembered is to-be evident, to be the-person and to-be at-ease (facilis) in being the-person, implicated, and at various distances from what I see and what enframes me as a subject of subjectivity. This governing, of and by oneself, that comes into writing (as a fact of being part of many institutions) is compelling - and into the body as the "being" compelled - in terms of "history"; this governing might be vague or strident. Foucault writes:

... if we understand by governmentality a strategic field of power relations in their mobility, transformability, and reversibility, then I do not think that reflection on this notion of governmentality can avoid passing through, theoretically and practically, the element of a subject defined by the relationship of self to self. (2001: 251)

I negotiate (with) my self (in this body) in a complex field of infinite and unexpected powers, some sympathetic, others antipathic - this is the world close-by (in direct touch with the-person-me), this then is the world of myself (a continual affected body in radiating space); the-person that writes contemplates herself (watches herself search for words to extend sense here, and fail):

We must [says Seneca, in Foucault] turn around to contemplate the self, in the very moment of flight ... It is the flight of time that is involved here, rather than the sage's flight or retreat. In the movement of time that carries us to the final point of our life, we must turn our gaze around and take ourselves as the object of contemplation. (2001: 263)

This "turn" would require practice, or a (creative) practice, an activity, to contemplate with (in the company of its material needs and limitations), to be in concert with, so as to watch (to experience) my/self as "something" making "something", to see how I "do my work" in time, as time passes; to watch making, to watch my/ 
self in "the flight of time". This "turn" is turned (around; it is pivotal; it circles, or faces the other way) in gravity; practice might entail moving through and against the forces of gravity - like an athlete or a dance (or a writer; or in the act of ordinarily walking, running, jumping) - everyday practices of attention to the tiny "bones" and soft "tissue". Practice is learning, turning (going around) is, as well, a movement of the soul as well as the development of freedom and calmness to "depart". There are techniques to learn - systems and arts, complex labyrinthine knowledges notions and concepts (like recipes and formulas for magic (the transformation of energies: the seeing of colours, shapes, ghosts; the hearing of trees, animals, stones) - for mind and body's imagination, its image-making heart-role, during the brief time given to create "self" and the tiny space "self" occupies in the world.

\section{Scenario three}

I began this writing before the two scenarios above; that beginning is now later in the paper and begins with a sentence I was trying to resolve as a sentence: "Alchemical moments; the alchemy of writing; that is, not 'the writing' but the activity, the mixing and stirring, the waiting." I meant that writing is not, as a text, alchemical - although eventually it is (in its taking place somewhere in time-past) - but that the labour of its production is alchemical. I was "trying" to write an underside or a thin (convoluted) skin or an interior space (something that is usually hidden or at least unsaid); trying-out, attempting, endeavouring. ${ }^{4}$

I was trying, in the sentence, to connect the doing of "writing" to another old practice that puts various substances together, in various proportions and strengths, through a long process (of ritual, spell, heating, cooling) to make them something else, unimaginable even: I was putting a story into a sentence. Now this "story" is later in the text, below the scenarios, or substances. "Trying" is a practice, an endless attempting, in this instance, to write with a technic-without-technic tracing-movement (small moves toward/with small moves; perhaps then, "a scenario" is a small-event, or a small-shape, in history). However the beginning of the second half of this text - influenced by Francois Jullien's The Silent Transformations - (about the slow cumulative changes that turn love into hate, strength into weakness, light into dark), and, as mentioned, Michel Foucault's lecture of "17 February 1982, First Hour" - made possible a pause, a suspension, as someone (I remembered) was writing the writing, and was therefore a "topic" with the topic being written about (writing); there was silence, memory-without-memory, forgetting-without-forgetting.

\section{Scenario four}

The writing that begins with the alchemy-sentence is aware of Scenario One and Scenario Two although it was being written before the scenarios, to some degree. Initially, the text aimed to write about the writing of Hélène Cixous as a-life-writing, a-life-in-history, a land/personscape, a transforming-selfscape; this emerges in non-linear time, in fractal "figures"; shards of thought and feeling are caught, like dust, as they flow (onto and through matter) like dreams (not great big jumps, but tiny shifts as if "turning":

3 "This is to say, we should seek our objective, happiness and ultimate good in ourselves, in our minds, in the quality of our soul ... what is important is to be free to depart, to have the soul on our lips.... and being ready to die" (Foucault 2001: 265)

4 The Macquarie Dictionary, 3rd edition, The Macquarie Library Pty Ltd., University of NSW, Sydney, 1999: 2270.
How limited the imagination is. 'Go with him to the last train' had just taken the place of the last hour, now put off to the station, and never had I felt so poor in spirit so dried up, so lacking in great and admirable ideas, so ill served by memory, vain regrets needled me, I haven't prepared for the exam, nothing comes to mind, ah if only I could reread Plato, 
Montaigne, here we are, a reprieve is granted me, I mean Him, a day is rendered deific, and in advance unforgettable, and there I am thwarted by the advent of a delay which fills me on the one hand with archangelic bliss, on the other hand and at the same time with the inertia that prefigures death. (Cixous 2011: 18)

These "shards", as they come-and-go, create "circumstantial" writing that forms and unforms. However, I returned to self (perhaps though not to the "real-self") via making, like objects - vaguely imagining the four sculptural works below, from a series by Louise Haselton, titled "Veto Group $1 \& 11$ " - Scenarios 1, 2, 3 (\& 4) to see if I could see what I become in writing, or have already come-to-be; writing though writes beyond me-subject, far ahead.

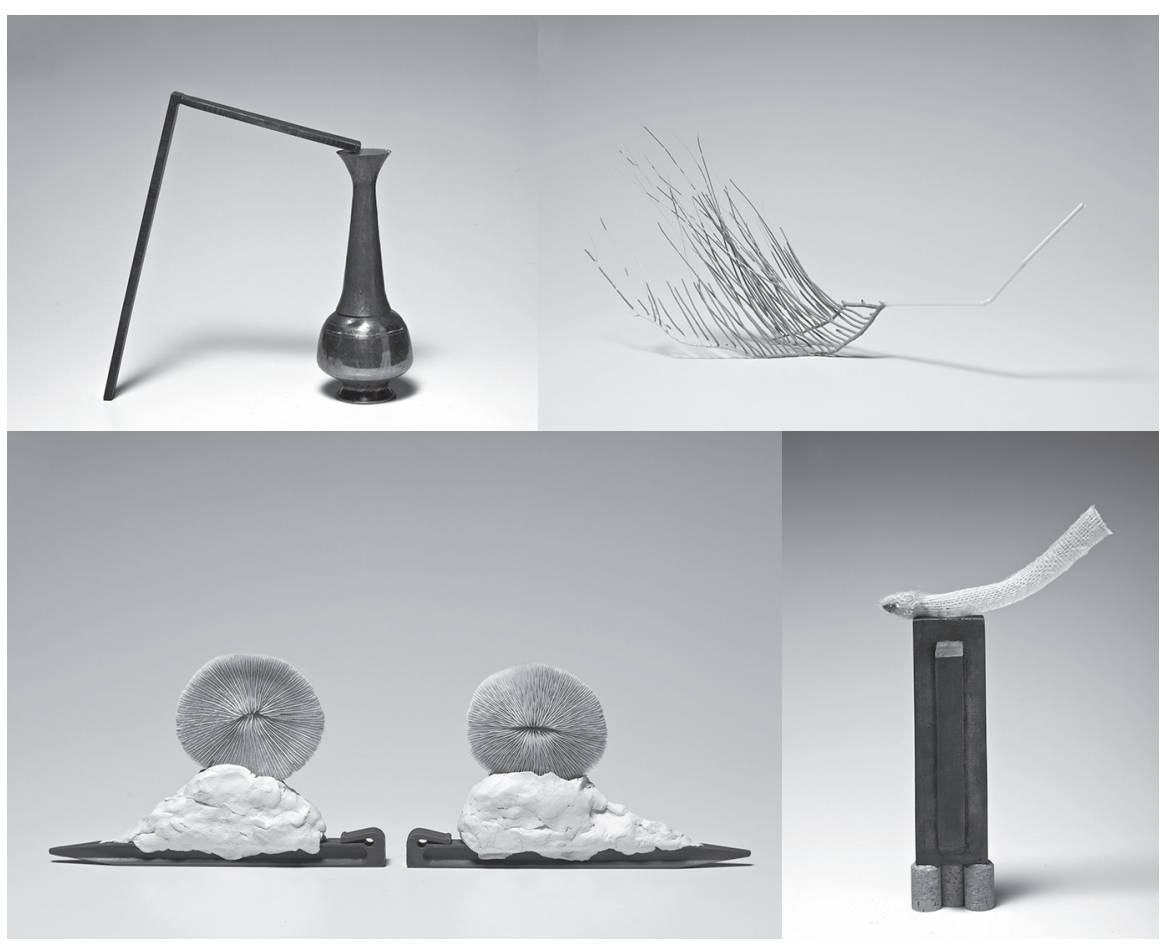

Fig. 1 Louise Haselton, Veto Group 1 \& 11 (2011) [selected objects].

\section{Second half, many lines}

Alchemical moments; the alchemy of writing; that is, not "the writing" but the activity (the labour, labouring), the mixing and stirring, the waiting. ${ }^{6}$

What I'm "trying" to come-to in writing is unscripted (as a form), is unintended (as an outcome), and is a compound body, impermanent, probably excessive and emotional and dependent.

The text, in its making, becomes always-other (in its passing), being momentarily here, and in a sense, "plastic", having form that bursts its own form, and yet is also a resistant (having visible and invisible attributes and subsequent laws).

This writing is an artwork (painting- or drawing-like, only suggestively so) rather than an informational vehicle for a "topic" - it represents itself as itself and is
5 Extracted from Louise Haselton, "Veto Group 1\& 11", in the exhibition titled Errand Workshop, Contemporary Art Centre of South Australia, Adelaide, July 2011; materials include: coral, straws, sea sponge, clay, rubber cork, brass, bronze (see also, footnote 7).

6 The use of the word "alchemy" here is intended in the spirit of its commonsense: any magical process of transmuting/ transforming; with "magic" meaning an act, an activity, of producing effects by supernatural agencies or forces (or irresistible influence), a reality outside "reality" (extra-real, magic-realism), and of course "reality" is a realm at issue; "chemical" plus "al" (the) = the-chemical; "chemical" from the Greek base kheo, to pour, flow, melt; and from the Greek khumos, the juice, an infusion: the-mix of juices that become other than themselves; substances touched by substances. See: Taussig 2011; Antonin Artaud's spell-casting in Derrida and Paule Thévenin 1998; Brian Massumi 2011 for fine sprinklings/ripples of the magic of processes of life throughout - via Alfred Whitehead, William James and Gilles Deleuze: "You have to open [things] back up. You have to give the thing its distances back ... [Deleuze] quotes Francis Bacon: you have to make a Sahara of it. You do this, in Bacon's words again, as a "matter of fact". Not as a matter of principle. Not as a matter of opinion.

... Not to represent. Not to reflect. Instead, as an event. In a drop of lived relation that has a style all of its own, that exemplifies its own singular-generic logic, and is as really appearing as it is infinitely expansive." 
7 Louise Haselton's objects in her exhibition "Errand Workshop" (see footnot 5) provide the visual occurrences for this "sociality" - they are purposeless, yet fascinating, they give pleasure. Michael Newall asked Haselton: "Reappraising the cast-off and overlooked seems a kind of strategy in your work. Is that right? It seems at the root of many of the pleasurable surprises and uneasy moments your work delivers." Haselton responded: "Re-presenting the overlooked is important in my work. I'm interested to see if the simple act of presenting something cast-off can be restorative. It's very satisfying to scrounge for unloved materials and objects and then resuscitate them. That can be simply through giving them new company, by combining a rock with some packaging, say, or some shells with chain; to point to another life or function something could hold. The potential of things can lie latent and be animated through a simple act" (Extracting Response: Michael Newall In Conversation with Louise Haselton, in Louise Haselton, Errand Workshop, Contemporary Art Centre of South Australia, Adelaide, August, 2011: 22).

8 ".... what I mean is this: if we take the question of power, of political power, situating it in the more general question of governmentality understood as a strategic field of power relations in the broadest and not merely political sense of the term, if we understand by governmentality a strategic field of power relations in their mobility, transformability, and reversibility, then I do not think that reflection on this notion of governmentality can avoid passing through, theoretically and practically, the element of a subject defined by the relationship of self to self" (Foucault 2001: 252) its own subject; in that mode it seeks and keeps company, it is sociable - words, thoughts, sentences, orders, punctuations, senses, appearances, times, contexts. ${ }^{7}$

The care of the life of the "thing/text/self", of its movement toward, or away from, what it "is" (in that it already is on or within a trajectory, acknowledged or not) is an art (better perhaps to say "fiction" or "poetry" or "space") - the establishing of a tekhne (a set of practices, that are dependent themselves upon the actual state of the self) for which a sense of health is primary, whether robust or fragile.

Writing moves from one point to another, traveling, traveling, negotiating as if aiming for a place, somewhere unknown and temporary. This shelter, or port, that is sought is a home (a home on the way home). This invokes the setting-out, the writing, to be something of an over-the-sea-passage, exhausting, time-consuming, and hopefully funny and joyful, a longing for arrival/rest. It is simultaneously a trip for the self:

... this idea of navigation [I have used the word 'negotiation', thinking less of destination] ... this dangerous journey to the port [of the self advancing towards something that is (her)self] ... implies a knowledge, a technique, an art, in order to be undertaken well ... a complex, both theoretical and practical knowledge, as well as being a conjectural knowledge, which is very close ... to the knowledge of piloting. (Foucault 2001: 263)

The use of these ideas ("navigation", "piloting") might help glimpse another sort of life; a life that doesn't give-up "the self”, as a requirement of engagement (and value). Tension gathers around the task of navigation/negotiation, amidst the conditions of political power, and of remembering the relationship with oneself that includes the things one thinks about, imagines, and makes (often to the governed beat of a governed drum). ${ }^{8}$ Can writing learn about itself, discover what it is (or how it might otherwise-be) and how it can conduct its life, so as to "... investigate what ought to be done ... [rather] than what has been done" (Foucault, quoting Seneca, 2001: 269); what does writing turn to (or away from) so as to best spend its life (so as to be ready to die); to live then, for-life: "... an enterprise of [delicate] health ...”, writes Deleuze (1997: 4); be/fore life perhaps, writing that is just before oneself, just before one gets to oneself as life, there, it leads, but is also that which is right before/under one's nose (or eyes). A writing that, in its coming to be, becomes writing: "The ultimate aim of [writing] is to set free, in the delirium, this creation of health or this invention of a people [to which I must belong], that is, a possibility of life" (Deleuze 1997).

Writing works with form (it works into form, it works in the community of forms), it appears, is visible, has affects. If we keep repeating, to more or less degree, the same form, then what "idea" or "limit" or "prejudice" are we blind to (blind in that we cannot see we cannot see), in that the form as the "acclaimed" form, hides within it a way of structuring knowledge (or living), a way of constructing meaning in terms of particular framings of time and of space (linear (beginning, middle, end) or circular (with a centre, a receptacle), tenses, organisation, clarity, etc). How, asks Catherine Malabou, can we "... think form itself in a more subtle and supple manner?” (2010: xviii). Jacques Derrida and Jean-Luc Nancy (and others) conceive of time as spacing ("the becoming-time of space and the becoming-space of time") (Malabou 2010: xxi); a way opens for thinking around "plasticity", around the materiality of form (and not opposing and matter), a plasticity that is both elastic and resilient, explosive and proliferating. Writing materially, in terms of plasticity 
- giving, taking, shattering - is a branching or diverging endeavour; Derrida, in the foreword to his book on Jean-Luc Nancy, sets out this way:

Hypothesis: it's going to be a lengthy tale with mythological overtones 'One day, once upon a time ...' Pruning, omitting, retelling, lengthening, with little stories, with a succession of touches touched up again, off on one tangent and then another, that's how I'm going to sketch the recollections of a short treatise dedicated to Jean-Luc Nancy that I have long been dreaming of writing [on Aristotle's On the Soul] - a murky, baroque essay, overloaded with telltale stories (wanting to spell trouble), an unimaginable scene that to a friend would resemble what has always been my relation to incredible words like 'soul', 'mind', 'spirit', 'body', 'sense', 'world', and other similar things. (2005: 7)

It's endless; writing becomes un-enclosed and not re-enclosable, spaced-out, deferential - awaiting more life-living, awaiting the blossoming of a different brain; a writing that is inconsistent (and re-worked and re-edited, re-cycled, re-composed). From Cixous's writing I feel how life moves within thought; I feel the movement of thought in writing as writing comes to live in the world; I feel how the world moves through the circumstances of a body at the time of its time, in writing. The philosophy/poetic of writing orients her writing from within (inside-out); her writing writes orientation, slips and slides over-the-seas of languages, tenses and sensations.

Writing like Cixous (or anyone else) would be unproductive, and would miss the purpose of "circumstantial" writing, a writing that must always be itself, in relation to the one-writing; each writing is then of its "own-itself", a "re-presentation" as a presentation unlike any other presentation - that is, how something is (uniquely, personally) seen, what it is (the seen) as "remains", as marks, as traces; for example, what have I been told/read, why was it told/written like that, how (with my disposition) do I then tell/write?

When writing writes (as if) fiction-writing non-fiction, when writing re-calls, callsout, it is humble, as it gathers ground, bit by bit, inside the idea or/and the self; it can't keep its distance from demons, ghosts, secrets, pain, murder, loneliness, ecstasy, love, birth, death, addiction - from the hauntings, from the heart and soul, from being unstuck. Cixous writes:

... I don't stick to the side of conceptual reasoning, even if there is a certain capacity for abstraction there. In my text everything remains stubbornly concrete. The material for any text of mine is the raw stuff of everyday life. There are cars and very specific makers of car[s], saucepans, jam jars, plane tickets - all the accessories of life, both as common objects and as metaphors. (2009: 9)

This writing is spread-out, close to the ground, and in-memory of its subject, and of the subject who-writes. Derrida, writing on the death of his friend Paul de Man, and on his use of the phrase in "memory of", writes that "... any name, any nominal function, is 'in memory of' - from the first 'present' of its appearance, and finally, is 'in virtually-bereaved memory of' even during the life of its bearer" (Derrida, in Royle, 2009: $\mathrm{x}$ ). Writing is in-memory of others and their memory of memories (of others). 
Writing emerges in writing by differing speeds, textures, inserts, erasures, coming into shapes and forms one after the other, as "objects", as "entities", with their own internal qualities and durations, and affected by their specific close-encounters (their place in the writing's arrangement). The text alive, a world of space and time in which strange situations and events can arise and dissolve.

If the text looked back, what would it be as a creature/world (at every new appearance); what would look at me (and with what type of eye), and what would it see; if I looked into its gaze what would I see, and what would I be in that turned-back gaze; in the meantime there is this arrangement, a preparation for trying-again - lines making (for care) pockets, receptacles, cavities, of lineages; linings in/for the world.

\section{References}

Cixous, H. (2004). The writing notebooks (S. Sellers, Trans.). London, New York: Continuum.

Cixous, H. (2009). White ink: Interviews on sex, text and politics. New York, NY: Columbia University Press.

Cixous, H. (2011). Hemlock: Old women in bloom (B. Bie Brahic, Trans.). Cambridge, England: Polity Press.

Deleuze, G. (1997). Literature and life. In Essays critical and clinical (D. W. Smith \& M. A. Greco, Trans.). Minneapolis: University of Minnesota Press.

Derrida, J. \& Thévenin, P. (1998). The secret art of Antonin Artaud. (M. A. Caws, Trans.).

Cambridge, Mass.: The MIT Press.

Derrida, J. (2005). On touching - Jean Luc Nancy (C. Irizarry, Trans.). Stanford, NY: Stanford University Press.

Foucault, M. (2001). 17 February 1982: First hour. In The hermeneutics of the subject: Lectures at the Collège de France, 1981-1982 (G. Burchell, Trans.). New York, NY: Picador.

Hillman, J. (2007). The thought of the heart and the soul of the world. New York, NY: Spring Publications, Inc.

Jullien, F. (2011). The silent transformations (K. Figalkowski \& M. Richardson, Trans.). London, New York: Seagull Books.

Malabou, C. (2010). Plasticity at the dusk of writing: Dialectic, destruction, deconstruction (C. Shread, Trans.). New York, NY: Columbia University Press.

Massumi, B. (2011). Semblance and event: Activist philosophy and the occurrent arts. Cambridge, Mass.: The MIT Press.

Royle, N. (2009). In memory of Jacques Derrida. Edinburgh, Scotland: Edinburgh University Press. Taussig, M. (2011). I swear / saw this. Chicago and London: The University of Chicago Press. 